\title{
Inhibition Activity of Water Hyacinth Leaf Extract (Eichornia Crassipes) to the Growth of Subgingival Plaque Bacteria Colony
}

\author{
Ayu Arismawati ${ }^{1}$, Noer Ulfah ${ }^{2}$, Lambang Bargowo' \\ ${ }^{1}$ Undergraduate Student of Dental Medicine Faculty, Airlangga University, Surabaya-Indonesia, \\ ${ }^{2}$ Lecturer in Department of Periodonsia Dentistry, Faculty of Dentistry, Airlangga University, Surabaya, Indonesia
}

\begin{abstract}
Background: Periodontitis is an infectious disease in periodontal tissue and is able to cause a plaque that contains bacteria on the teeth. These bacteria colonize the oral cavity, invade the periodontal tissue, and attack the body's host system. Indonesia has many floras and one of them is called Water hyacinth. This flora is commonly known as waste because its abbility to pollute the environment. However, water hyacinth has a useful material including alkaloids, flavonoids, and tannins that can be used as the antibacterial agents. The study aims to determine the effect water hyancinth leaf extract (echiorniacrassipes) to the growth of subgingival plaque bacteria colony. Method: The study was conducted by using serial dilution techniques in the BHIB media with $100 \% ; 50 \% ; 25 \% ; 12,5 \% ; 6,25 \% ; 3,125 \% ; 1,56 \% ; 0,78 \%$ concentrations and planting on MHA medium. The analysis method in this study uses the Shapiro-Wilk Test, Levene's Test, and statistical tests with One-Way Anova.

Results: There are significant differences at the growth of sub gingival plaque bacteria. There is no growth of subgingival plaque bacteriain groups of $100 \% ; 50 \% ; 25 \% ; 12.5 \%$ and $6.25 \%$. The growth of subgingival plaque bacteria colonies was only seen at $3.125 \%$ concentration and increased the number of bacteria colonies at a $1.56 \%$.
\end{abstract}

Conclusion: Water hyacinth leaf extract was effective to inhibit the growth of sub gingival plaque bacteria colonies.

Keywords: Antibacterial, bacteria colonies, Eichorniacrassipes, sub gingival plaque bacteria.

\section{Introduction}

Periodontal disease and dental caries are two diseases that mostly affect the severity of dental and oral diseases. Tooth loss in adults is a result of the severe periodontal abnormalities and is found in $5-15 \%$ of the world's population ${ }^{1,2}$.

\section{Coresponding Author:}

Noer Ulfah

Lecturer in Department of Periodonsia Dentistry, Faculty of Dentistry, Airlangga University, Surabaya, Indonesia

e-mail: noer_ulfah@yahoo.com
Periodontitis is an infectious disease in periodontal tissue with various manifestations, starting from inflammation of the gingiva, formation of periodontal pockets, loss of supporting bone until the occurrence of a date tooth ${ }^{3}$. In addition, this disease is also characterized by the inflammation that causes damage to collagen fibers, the gingival matrix, periodontal ligaments, and alveolar bone ${ }^{4}$. Periodontitis is often associated with infections from various bacteria, such as Porphyromonasgingivalis, Tannerella forsythia and Aggregatibacteractinomycetemcomitans. The occured tissue damage tha is the result of complex interactions of these bacteria with the response of the host as well as the inflammatory process ${ }^{5}$. 
During the inflammation process, bacterial products are released and penetrate into the periodontal tissues. Afterward, those bacterial products activate the host immunoinflamatory response by producing cytokines and matrix metalloproteinase which can cause damage to the extracellular matrix of the periodontal tissue. The matrix metalloproteinase is a proteolytic enzyme that causes damage to the extracellular matrix, periodontal ligament, and the bone protein matrix. Thereby, MMP plays an important role in the regulation of periodontal tissue damage ${ }^{6}$.

Dental plaque is the main factor which causes the early periodontal abnormalities and known as gingivitis - a process of inflammation in the gingiva ${ }^{7}$. Plaque formation begins with the formation of dental pellicles on the clean surface of the tooth in minutes. These bacteria can bind to receptors on the dental pellicle. Initial colonization is started by gram-positive facultative bacteria, such as A. viscosus, $S$, sanguis. This plaque develops rapidly in the early development of the biofilm and progressively slows down during the biofilm maturation ${ }^{8}$. The next stage is secondary colonization by bacteria such as Prevotellaintermedia, Prevotelleloescheii, Capnocytophagaspp, Fusobacteriumnucleatum, and Porphyromonasgingivalis. These bacteria have the ability to attach at the different species of plaque microorganisms. If the plaque is not cleaned, it will develop into the subgingival area which causes subgingival plaque formation ${ }^{9}$.

Nowadays, the modern medical world of the molecular field is very advanced, but this does not stop the traditional medicine to exist. This is proved by the many traditional medicines that are widely used by the medical world to treat diseases. Some plants are known for their antibacterial activity ${ }^{10}$.

Water hyacinth is a plant that floats on the surface of the water as well as has thick leaves and air-filled stems which make this plant float. This plant is considered disturbing because it can spread in large areas of the water and cover the surface of the water. Thereby, it can reduce the light that penetrate trough the water and result in reduced oxygen in the water. Other affect include silting the lake or other waters due to water hyacinth that dies and settles on the bottom. But the content of the water hyacinth plants is secondary metabolites of alkaloids, flavonoids, tannins, which known as antibacterial, antiviral, and anticancer ${ }^{11}$. Based on the background, the aims of the study is to analyse the inhibition activity of water hyancinth leaf extract (echiorniacrassipes) to the growth of subgingival plaque bacteria colony.

\section{Material and Method}

This type of research is a laboratory experiment with the design of the Post-Test Only control group design $^{12}$. This research was conducted in the Research Center Dental Medicine Faculty, Airlangga University and Pharmacy Laboratory, Airlangga University, East Java.

The tools and materials used are test tubes and shelves, buchner funnel, petri dish, glass gourd, incubator, micropipette, osse, spreader, rotary evaporator, scales, auctoclave, water hyacinth leaf extract (Eichornia Crassipes), subgingival plaque bacteria stock, Brain Heart Infusion Broth (BHIB) media, and Mueller Hinton Agar (MHA)media

Making Hyacinth Leaf Extract: Water hyacinth leaves are dried with oven in $50^{\circ} \mathrm{C}$ until dry. After the drying process, then the grinding one is conducted using a blender to get water hyacinth powder granule, as much as 600 grams of water hyacinth leaves macerated with $2500 \mathrm{ml}$ ethanol $96 \%$ solvent. Moreover, stirred with a stirrer for 24 hours and filtered using whatmann paper which is placed on a Buchner funnel and obtained by filtrate. Centrifuged $50 \mathrm{rpm}$ for 24 hours. The sediment obtained is then evaporated using a rotary evaporator for 4 hours. Finally, the conduct and evaporation above the water bath until finished, and then evaporated again until there is no residual ethanol content.

Stage of Inhibition Activity Test for Water Hyacinth Leaf Extract to The Growth of Subgingival Plaque Bacteria

The inhibitory test in this study uses a liquid dilution method with serial dilution as well as some steps. Firstly, we have to prepare 9 test tubes with 1 test tube containing subgingival plaque bacteria stock which has been prepared and labeled. The test tube no. 1 containing $10 \mathrm{ml}$ of water hyacinth leaf extract, eight other test tubes filled with BHIB media as much as $5 \mathrm{ml}$. After the other eight tubes were filled with BHIB, $5 \mathrm{ml}$ of extract was put in the tube no. 1 then stirred it. Afterward, $5 \mathrm{ml}$ of liquid from the tube no. 1 were taken and put in tube no. 2 and stirred again. The next one, $5 \mathrm{ml}$ of liquid from the tube no. 2 are taken and put in the tube no. 5. Stirred it again, and repeated until the liquid is put in the tube No. 8. In additiom, the $5 \mathrm{ml}$ of liquid from tube no. 8 
is removed so that the liquid in each tube has the same liquid volume.

After all of the media are prepared, $1 \mathrm{ml}$ of subgingival plaque bacteria stock is inserted into each tube containing a mixture of BHIB and the extract. The remaining tubes containing only $5 \mathrm{ml}$ of BHIB media were negative controls, and the tubes containing subgingival plaque bacteriastock were positive controls. All the treatment above was repeated three times to obtain adequate sample size. The tubes were incubated at $37^{\circ} \mathrm{C}$ for 24 hours
After 24 hours incubated, each tube is taken 1 osse and planted on Mueller Hinton Agar (MHA) media by strike move to check there is bacteria growth or not. Incubation is conducted for 24 hours at $37^{\circ} \mathrm{C}$. After the second incubation, we have to take $0.1 \mathrm{ml}$ from the boundary tube between the bacteria growth and the nonpositive. The negative control then planted on the MHA media. Enter it into the incubator at $37^{\circ} \mathrm{C}$ for 24 hours. Calculates the number of bacteria colonies that grow on MHA media after the last incubation and do the data analysis.

\section{Results}

The results of this study can be seen from the number of subgingival plaque bacteriacolonies growth.

Table 1. The number of subgingival plaque bacteriacolonies given water hyacinth leaf extract (Eicchorniacrassipes) at a concentration of 1,56\%-100\%

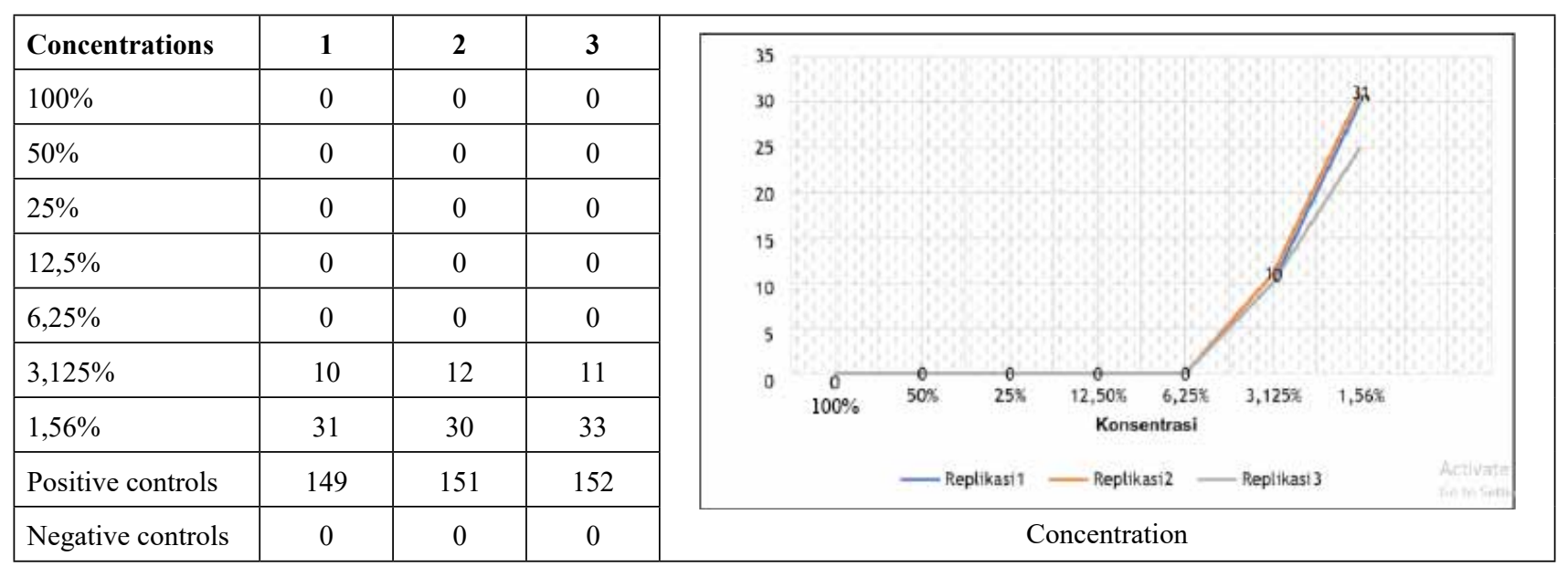

Based on the results of the study it can be seen that there is no growth of subgingival plaque bacteriain groups of $100 \% ; 50 \% ; 25 \% ; 12.5 \%$ and $6.25 \%$. The growth of subgingival plaque bacteria colonies was only seen at $3.125 \%$ concentration and increased the number of bacteria colonies at $1.56 \%$.

The measurement results are tabulated according to each group sample and followed by testing the normal distribution using the Shapiro-Wilk Test with Sig $>0.05$. It can be concluded that the data are normally distributed. Afterward, the homogeneity testing using Levene's Test with Sig. $<0.05$ can be concluded that the data is homogeneous. Afterward, the statistical tests were conducted using One-Way Anova at the significance level of Sig. $<0.05$ and significant differences were obtained. Finally, it then continued by performing multiple comparisons using Post-hoc TukeyAnova which concluded that all groups had significant differences.

\section{Discussion}

The results of the analysis showed that the number of colonies at a concentration of $3.125 \%$ had a significant difference with the number of colonies at a concentration of $1.56 \%$ and positive control. Likewise, the number of colonies in the extract of water hyacinth leaves concentration of $1.56 \%$ has a significant difference to the number of colonies in the positive control group. This shows that the extract of water hyacinth leaves at a concentration of $3.125 \%$ and $1.56 \%$ has a fairly good antibacterial effect. The results of this study also showed a bactericidal effect of $6.25 \%$ where subgingival plaque bacterial colonies were completely invisible and the 
inhibitory power was best at a concentration of $3.125 \%$, where the subgingival plaque bacteria could grow at minimal number. This is due to the presence of bioactive substances in water hyacinth leaves which have been studied as antibacterial, andthe quantity of concentration that contains bioactive substances that play a role in inhibiting bacteria.

Based on scientific research stated that water hyacinth leaf extract contains alkaloids, flavonoids, and tannins which are known to have antibacterial power that can inhibit bacterial growth ${ }^{10}$. The alkaloids contained in the hyacinth leaf extract has antibacterial biological activity that can interfere with the constituent components of the bacterial cell that make the cell wall not formed and easily get lysed ${ }^{11}$. Antibacterial flavonoids has a working mechanism that can interfere bacterial membrane synthesis, and inhibits bacterial metabolism - which can damage bacterial breeding pathways and damage bacterial membrane walls that will be followed by the bacterial death ${ }^{13}$. This compound will also interfere with the energy metabolism in a similar manner to the respiratory systembecause the energy demand for active absorption of various metabolites andthe biosynthesis of macromolecules insufficient so that lead to bacterial dead ${ }^{14}$. Tannin known to has antibacterial activity related to their ability to form hydrogen bonds which results in protein denaturation in the membrane so that cells experience damage. Membrane damage causes the fulfillment of nutrients needed by bacteria cannot be achieved. This can be disrupted the bacterial metabolism and reduce the bacterial energy ${ }^{15}$.

\section{Conclusion}

Water hyacinth leaf extract was effective to inhibit the growth of sub gingival plaque bacteria colonies. So, it is expected to preserve the water hyacinth plant and cultivate it.

Ethical Clearance: The research process involves participants in the survey using a questionnaire that was accordant with the ethical research principle based on the regulation of research ethic committee. The present study was conducted in accordance with the research principles. This study implemented the basic principle ethics of respect, beneficence, nonmaleficence, and justice.

Conflict of Interest: There is no conflict of interest for all authors
Source of Funding: This study is done with individual funding

\section{References}

1. Engström M, Eriksson K, Lee L, Hermansson M, Johansson A, Nicholas AP, et al. Increased citrullination and expression of peptidylarginine deiminases independently of $\mathrm{P}$. gingivalis and A. actinomycetemcomitans in gingival tissue of patients with periodontitis. Journal of translational medicine. 2018;16(1):214.

2. Petersen PE. The World Oral Health Report 2003: continuous improvement of oral health in the 21st century-the approach of the WHO Global Oral Health Programme. Community Dentistry and oral epidemiology. 2003;31:3-24.

3. Kinane DF, Stathopoulou PG, Papapanou PN. Periodontal diseases. Nature Reviews Disease Primers. 2017;3(1):1-14.

4. Ilgenli T, Vardar-Sengul S, Gürkan A, Sorsa T, Stackelberg S, Köse T, et al. Gingival crevicular fluid matrix metalloproteinase-13 levels and molecular forms in various types of periodontal diseases. Oral diseases. 2006;12(6):573-9.

5. Silva N, Dutzan N, Hernandez M, Dezerega A, Rivera O, Aguillon JC, et al. Characterization of progressive periodontal lesions in chronic periodontitis patients: Levels of chemokines, cytokines, matrix metalloproteinase-13, periodontal pathogens and inflammatory cells. Journal of clinical periodontology. 2008;35(3):206-14.

6. Gursoy UK, Liukkonen J, Jula A, Huumonen $\mathrm{S}$, Suominen AL, Puukka P, et al. Associations between salivary bone metabolism markers and periodontal breakdown. Journal of periodontology. 2016;87(4):367-75.

7. Al-Bayaty FH, AI-Koubaisi AH, Ali NAW, Abdulla MA. Effect of mouth wash extracted from Salvadora persica (Miswak) on dental plaque formation: a clinical trial. J Med Plant Res. 2010;4(14):1446-54.

8. Marsh PD, Moter A, Devine DA. Dental plaque biofilms: communities, conflict and control. Periodontology 2000. 2011;55(1):16-35.

9. Alzoreky NS, Nakahara K. Antibacterial activity of extracts from some edible plants commonly consumed in Asia. International journal of food microbiology. 2003;80(3):223-30. 
10. Muladi S. Kajian Eceng Gondok sebagai Bahan Baku Industri dan Penyelamat Lingkungan Hidup di Perairan. In: Prosiding Seminar Nasional IV Masyarakat Peneliti Kayu Indonesia (MAPEKI) Samarinda. 2001.

11. Retnowati $\mathrm{Y}$, Bialangi N, Posangi NW. Pertumbuhan bakteri Staphylococcus aureus pada media yang diekspos dengan infus daun sambiloto (Andrographis paniculata). Sainstek. 2011;6(2).

12. Berniyanti T, Fardhani A, Palupi R, Bramantoro $\mathrm{T}$, Ramadhan D, Ramadhani A, et al. Effect of blood iron level on prevalence of recurrent aphthous stomatitis (RAS) in traffic police officers. Indian Journal of Public Health Research and Development [Internet]. 2019;10(8):1103-8. Available from: https://www.scopus.com/inward/ record.uri?eid=2-s2.0-85073549846 \& doi $=10.595$ 8\%2F0976-5506.2019.02044.8 \& partnerID $=40 \&$ md5=5669a15aeaf32c85a7252aea2fdfc59e

13. Roy R, Tiwari M, Donelli G, Tiwari V. Strategies for combating bacterial biofilms: A focus on antibiofilm agents and their mechanisms of action. Virulence. 2018;9(1):522-54.

14. Cushnie TPT, Lamb AJ. Recent advances in understanding the antibacterial properties of flavonoids. International journal of antimicrobial agents. 2011;38(2):99-107.

15. Sofiane G, Wafa N, Ouarda D. Antioxidant, antimicrobial and anti-inflammatory activities of flavonoids and tannins extracted from Polypodium vulgare L. Asian J Biochem Pharm Res. 2015; $5: 114-22$. 